\title{
Factors Predicting Organizational Commitment among Nurses in State Hospitals, Malaysia
}

\author{
Siew PL, ${ }^{\mathrm{a}}$ Chitpakdee $\mathrm{B},{ }^{\mathrm{b}}$ Chontawan $\mathrm{R}^{\mathrm{b}}$ \\ a Faculty of Nursing, International Islamic University of Malaysia (IIUM) \\ b Faculty of Nursing, Chiang Mai University, Thailand
}

\begin{abstract}
Introduction: With an increase in national nursing shortage, organizational commitment is extremely important for retention of nurses. This predictive study determines the level of organizational commitment and the predictive ability of perceived organizational support, components of job satisfaction, including pay, task requirement, organizational policies, autonomy, interaction and professional status as well as years of experience on organizational commitment. Method: Data were collected from 416 nurses in four state hospitals in Malaysia, using self-administered questionnaires. The hospitals were selected from each region in Peninsular Malaysia and samples were selected by a random sampling method. Questionnaires, including demographic data, Organizational Commitment Questionnaires, Survey of Perceived Organizational Support, and Index Work Satisfaction were distributed by researcher and research assistants. Stepwise multiple regression technique was used to analyze the data. Results: The results discovered that (1) nearly half of the subjects $(48.07 \%)$ reported high level of organizational commitment. (2) Professional status, autonomy, interaction, task requirement and years of experience could predict the organizational commitment $(\beta=0.52$, $0.17, p<0.01$ ); $\beta=0.13,0.11,0.09, p<0.05$ respectively). Overall, all predictors explained $33 \%$ of variability in the organizational commitment among nurses in state hospitals. Conclusions: This study found that nurses in state hospitals were highly committed to their organizations. Results of this study provide information for nurse administrators to consider and maintain these factors in nursing practice to foster a high level of organizational commitment among Malaysian nurses.
\end{abstract}

KEYWORDS: Organizational management, health planning organization, nurses, job satisfaction, policy, Malaysia.

INTRODUCTION

Nursing shortage is a major problem in the healthcare setting throughout the world and it is a major symptom of high turnover rate in the healthcare industry. High nurse turnover can negatively impact an organization's capacity to meet the patient's need by interrupting the continuity of patient care. ${ }^{1}$ In order to deal with nurses' turnover, most of the healthcare organizations increase the recruitment and retain nurses to maintain adequate staffing. Although increasing recruitment of nurses may help to offset the problem of nursing shortage in the short term, retaining them may be the best strategy in the long term because a healthcare objective is to maintain high quality of care at reduced costs.

Among the factors that contributed to high retention,

Corresponding author:

Siew Pien Lee

Kulliyyah (Faculty) of Nursing,

International Islamic University of Malaysia

P. O. Box 141, 25710 Kuantan,

Pahang, Malaysia.

Tel. No.:+60192808095

Fax No: +609513 3615

Email: siewpien@yahoo.com organizational commitment has been found as an antecedent. ${ }^{1,2,3}$ Organizational commitment refers to the extent to which an individual's identification with involvement in a particular organization. ${ }^{4}$ The highly committed nurses tend to stay in their current organizations as studies found that retention of employees was positively correlated with organizational commitment. .,6 $^{5}$

Previous studies found that a lot of variables were related to organizational commitment among nurses such as organizational characteristic, ${ }^{1}$ work condition, ${ }^{7}$ perceived organizational support, ${ }^{1,8}$ job satisfaction, ${ }^{8-12}$ and employees' characteristic such as age, educational level, and years of experience. . $^{9,13,14,15}$ However, perceived organizational support (POS) was frequently found to be factors predicting organizational commitment in studies conducted in various settings. Organizational support is an assistance provided by the organization to the employees to carry out their job effectively and to deal with stressful situations. ${ }^{16}$ Perceived organizational support (POS) is when the employee form a global belief about the extent to which an organization values their contributions and care of their well-being. ${ }^{2}$ Nurses who perceived that their organizations support their contributions and well-being by assisting them to do their job effectively and to deal with their stressful situations will be committed to their organizations and will have a sense of loyalty Volume 10 Number 2, Dec 2011 
than those who do not perceive it so. This belief was confirmed by a study that showed nurses who worked in organizations that valued their contributions and cared for their well-being were highly committed to their organizations. ${ }^{1}$

Job's satisfaction was another factor frequently found to be positively correlated with an organizational commitment. Job's satisfaction is the extent to which an individual likes his or her job. ${ }^{17}$ Nurses who were satisfied with their job also felt happy and stayed in their organizations, as many studies found that high level of job satisfaction contributed to a high level of organizational commitment amongst employees. ${ }^{8,9,10,15,18,19}$ In terms of components of job satisfaction, pay, autonomy, task requirement, organizational policies, interaction, professional status, work itself, promotion opportunity, supervision, and co-workers are frequently addressed in the nursing literatures. Nurses who were satisfied with these components were likely to stay in their current organizations. ${ }^{11,20-23}$

Besides job satisfaction and POS, year of experience is another factor positively related to organizational commitment among nurses in various studies. . $13,14,24^{2}$ Nurses with long years of experience tend to be more committed to their organization than those with short years of experience because the long period of working will accumulate to much benefit such as high salary, good pension plan, high increment, more vacation leaves, bonuses and other benefits. Furthermore, the longer nurses work with the organization, the more sense of belonging they feel as part of the organizations.

In Malaysia, the total number of nursing personnel is 79700 , which makes up $75 \%$ of the total healthcare workforce. Nevertheless, the turnover rate of nurses in Malaysia had increased more than 50\% from the year 2005 to the year 2010 with the number of 400 to 1049 nurses leaving their present workplace. In addition, Malaysia also faces the migration of nurses with an attrition rate of 400 per year and currently about 25,000 Malaysian nurses are working in other countries such as in the Middle East and other countries. ${ }^{25}$ Because of this situation; Malaysia is expected to face a shortage of nurses in the future. Malaysia is still facing a deficit of 7,000 nurses per year and it is estimated that a total of 70,000 nurses will be required by the year 2020. ${ }^{25}$

Nurses in most hospitals play an important role in taking care of clients 24 hours a day. They are the ones who have the variety of tasks to perform and need to cope with many tasks in many places in hospitals. At the same time, nurses are often blamed for declined standards of nursing care, rather than the structural factors such as staffing shortage, working conditions and lack of support. ${ }^{26}$

Literature showed that Malaysian nurses had low to moderate satisfactions towards their jobs in all Volume 10 Number 2, Dec 2011 the components of job's satisfaction, including satisfaction with supervisor, job variety, closure, compensation, co-worker, human-resource management or management policies, pay, task requirement, interaction, organizational policies, autonomy and professional status. ${ }^{27-30}$ There was no study found in Malaysia regarding POS, while for the organizational commitment, a study found that Malaysian nurses were more committed to their organizations compared to nurses in England. ${ }^{27}$ However, the study did not indicate the level of organizational commitment. In addition, there was no study regarding the correlation between each component of job's satisfaction and organizational commitment, and POS and organizational commitment in nurse population found in Malaysia.

Thus, inconsistency of results from the literature review regarding the relationship between components of job satisfaction and organization commitment from other countries, lacking of study regarding POS and organizational commitment and uncertainty in level of organizational commitment among nurses in Malaysia, the knowledge regarding POS, components of job's satisfaction and organizational commitment in Malaysia need to be further explored. Therefore, this study is to determine the level of organizational commitment and the predictability in organizational commitment that can be explained by factors, including POS, components of job satisfaction including pay, autonomy, task requirement, organizational policies, interaction, and professional status as well as years of experience on organizational commitment among nurses working in state hospitals in Malaysia. Results of this study will provide basic information for nurse administrators in developing appropriate strategies to enhance organizational commitment among nurses in Malaysia.

\section{METHODOLOGY}

\section{Conceptual framework}

Figure 1 is the conceptual framework of the study. The conceptual framework of this study believes that nurses, who perceived high organizational support, satisfied with each component of job satisfaction and had longer years of experience as a nurse will be committed to their organizations.

\section{Sampling technique}

This study was conducted in state hospitals in Peninsular Malaysia. Twelve state hospitals in Peninsular Malaysia were divided into four main areas according to the four regions which were northern region, east coast region, central region and southern region. Four hospitals were selected from each region to be the setting and 416 nurses were selected from four state hospitals by simple random sampling method, to complete the designed questionnaires. 


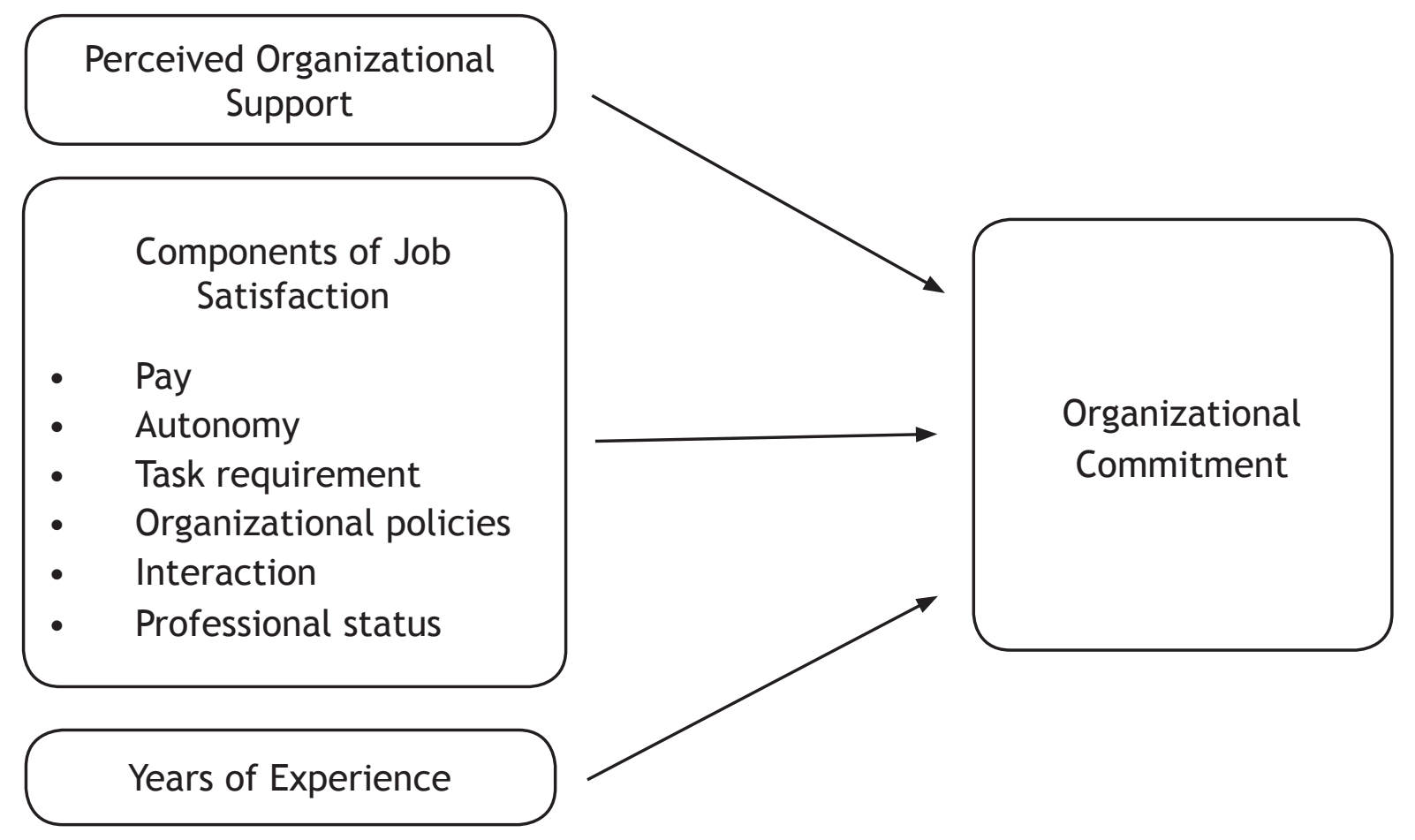

Figure 1. Conceptual framework of the study

\section{Instruments}

The instrument used in this study composed of four parts. Part one was demographic data developed by the researcher. Part two was 8 items of Survey of Perceived Organizational Support (SPOS) to measure perceived organizational support of nurses. ${ }^{31}$ Part three was part B (44 items) of Index of Work Satisfaction (IWS), ${ }^{17}$ and part four was 9 items of Organizational Commitment Questionnaires (OCQ). ${ }^{4}$ The response categories were using 7-point Likert like scale ranging from 1 (strongly disagree) to 7 (strongly agree). The negative worded items were reverse-scored. The scores were then summed and divided by the number of items to attain a mean. The instruments used were tested for validity and reliability in many different professions, including nursing. In this study, the internal consistency value of SPOS, IWS and OCQ were $0.80,0.80$ and 0.95 respectively. The internal consistency for components of IWS, including pay, autonomy, task requirement, organizational policies, interaction and professional status ranged between 0.67 to 0.72 .

\section{Procedure of data collection}

After approval from graduated committee, Faculty of Nursing, Chiang Mai University, Director of the four state hospitals in Malaysia and National Institute of Health, Ministry of Health, Malaysia, the package of questionnaires consisting: information sheet, inform consent forms, questionnaires, were distributed to the selected sample. The information sheet explained the objective of study, method for assurance of confidentially and anonymity, and time frame for completion of the questionnaires. The returned questionnaires were collected by the researcher after two weeks. Fifty-five of 471 returned questionnaires were excluded due to incomplete information, thus a total of $416(86.66 \%)$ of completed questionnaires were finally analyzed.

\section{Data analysis}

The data were analyzed using SPSS version 13.0. Demographic data of subjects, the scores of overall organizational commitment, POS, job satisfaction and components of job satisfaction were analyzed by using mean, and standard deviation. Factors predicting organizational commitment were tested by using stepwise multiple regression analysis after all the assumptions of multiple regression including normality of distribution, linearity, homoscedasticity were met.

\section{RESULTS}

Table I shows that the mean age of the subjects was 32 years $(S D=8.22)$ with the majority of the subjects were female $(96.40 \%)$, Malays $(97.35 \%)$ and married $(60.58 \%)$. In terms of educational level, the majority of the subjects had diploma qualification (81.73\%) and most of the subjects had a range of salary between RM 2001 to RM 2500 per month (33.41\%). With regards to the years of experience, the mean number of years of experience as a nurse was $8.52(\mathrm{SD}=7.72$ ) with most of the subjects being employed as a nurse for more than five years $(57.70 \%)$. In terms of participation in training programs, majority of the subjects participated in a training program (86.30\%), most of them had attended two to three times $(39.66 \%)$. 


\begin{tabular}{|c|c|c|}
\hline Characteristics of the subjects & $\mathrm{n}$ & $\%$ \\
\hline $\begin{array}{l}\text { Age }(=32.32, \text { SD }-8.22, \text { Range }=21-58 \text { years old }) \\
21-30 \text { years old } \\
31-40 \text { years old } \\
41-50 \text { years old } \\
51 \text { and above }\end{array}$ & $\begin{array}{l}223 \\
137 \\
33 \\
23\end{array}$ & $\begin{array}{l}53.60 \\
32.93 \\
7.93 \\
5.54\end{array}$ \\
\hline $\begin{array}{l}\text { Gender } \\
\text { Female } \\
\text { Male }\end{array}$ & $\begin{array}{l}401 \\
15\end{array}$ & $\begin{array}{l}96.40 \\
3.60\end{array}$ \\
\hline $\begin{array}{l}\text { Race } \\
\text { Malays } \\
\text { Chinese } \\
\text { Indian }\end{array}$ & $\begin{array}{l}405 \\
2 \\
9\end{array}$ & $\begin{array}{l}97.35 \\
0.49 \\
2.16\end{array}$ \\
\hline $\begin{array}{l}\text { Marital status } \\
\text { Single } \\
\text { Married } \\
\text { Divorced/separated/widowed }\end{array}$ & $\begin{array}{l}155 \\
252 \\
9\end{array}$ & $\begin{array}{l}37.28 \\
60.58 \\
2.14\end{array}$ \\
\hline $\begin{array}{l}\text { Nursing education } \\
\text { Certificate } \\
\text { Diploma } \\
\text { Bachelor Degree }\end{array}$ & $\begin{array}{l}44 \\
340 \\
32\end{array}$ & $\begin{array}{l}10.58 \\
81.73 \\
7.69\end{array}$ \\
\hline $\begin{array}{l}\text { Salary } \\
\text { RM } 1500-\text { RM } 2000 \\
\text { RM } 2001-\text { RM } 2500 \\
\text { RM } 2501-\text { RM } 3000 \\
\text { RM } 3001 \text { - RM } 3500 \\
\text { RM } 3501 \text { and more }\end{array}$ & $\begin{array}{l}123 \\
139 \\
116 \\
31 \\
7\end{array}$ & $\begin{array}{l}29.57 \\
33.41 \\
27.88 \\
7.45 \\
1.69\end{array}$ \\
\hline $\begin{array}{l}\text { Years of experience }(=8.52, \mathrm{SD}=7.72 \text {, } \\
\text { Range }=.50-35.33) \\
6 \text { months }-5 \text { years } \\
5.01-10 \text { years } \\
10.01-15 \text { years } \\
15.01-20 \text { years } \\
\text { More than } 20 \text { years }\end{array}$ & $\begin{array}{l}176 \\
111 \\
66 \\
29 \\
34\end{array}$ & $\begin{array}{l}42.30 \\
26.68 \\
15.87 \\
6.97 \\
8.18\end{array}$ \\
\hline $\begin{array}{l}\text { Participation in training programs } \\
\text { Yes } \\
\text { No }\end{array}$ & $\begin{array}{l}359 \\
57\end{array}$ & $\begin{array}{l}86.30 \\
13.70\end{array}$ \\
\hline
\end{tabular}

Table II depicts the overall score of organizational commitment of the subjects ranged from 14 to 63 $(=4.97, \mathrm{SD}=1.20$, Range $=1.56-7.00)$ with approximately $48.80 \%$ of the subjects had a high level of organizational commitment, $44.23 \%$ of the subjects had a moderate level of organizational commitment and $6.97 \%$ of the subjects had a low level of organizational commitment.

\begin{tabular}{|l|l|l|l|}
\hline Variable & Level of OC & $\mathbf{n}$ & $\%$ \\
\hline Overall score of OC & & & \\
$1.00-3.00$ & Low & 29 & 6.97 \\
$3.01-5.00$ & Moderate & 184 & 44.23 \\
$5.01-7.00$ & High & 203 & 48.80 \\
& & & \\
\hline
\end{tabular}

Table II. Number and percentage of nurses sample classified by levels of organizational commitment $(n=416)$

Table III showed the mean score for perceived organizational support was $4.61(\mathrm{SD}=0.92)$ with the range of score from 2 to 7 and the overall job satisfaction was $3.92(S D=0.50)$ with the range of score from
2.39 to 5.84. Of the six dimensions of job satisfaction, professional status had the highest mean score, 4.95 $(S D=0.83)$, followed by interaction $(\bar{X}=4.31, S D=$ $0.78)$, autonomy $(\bar{X}=4.12, S D=0.68)$, organizational policies $(=3.85, \mathrm{SD}=0.76)$, task requirement $(\bar{X}=$ $3.37, S D=0.72$ ) and pay with the lowest mean score $(\bar{X}=3.23, S D=0.97)$, and years of working as a nurse $(\bar{X}=8.52, S D=7.72)$.

\begin{tabular}{|l|l|l|l|}
\hline Variables & Range & $\bar{X}$ & SD \\
\hline POS & $2-7$ & 4.61 & .92 \\
Sub dimensions of job satisfaction & & & \\
$\quad$ Pay & 1.00 & 3.23 & .97 \\
$\quad$ Autonomy & & 4.12 & .68 \\
Task Requirement & & 3.37 & .72 \\
Organizational Policies & & 4.85 & .76 \\
Interaction & & 4.95 & .78 \\
Professional status & 3.92 & .53 \\
Total score of job satisfaction & & 8.52 & 7.72 \\
Years of working experience as a & & & \\
nurse & & & \\
& & & \\
\hline
\end{tabular}

Table III. Mean, standard deviation (SD) and range of the factors predicting organizational commitment 
$(n=416)$

As presented in Table IV, five factors were significantly predicting organizational commitment. Beta values showed professional status had a strongest predictive power ( $\beta=0.52, p<0.01)$, followed by autonomy $(\beta=0.17, p<0.01)$, interaction $(\beta=0.13, p<0.05)$, task requirement $(B=0.11, p<0.05)$, and year of working as a nurse $(B=0.09, p<0.05)$. Overall, all predictors could explain $33 \%$ of variability in the organizational commitment among nurses in state hospitals.

\begin{tabular}{|l|l|l|l|l|l|}
\hline Variables & B & B & SE & t & p \\
\hline & & & & & \\
Professional status & 0.76 & 0.52 & 0.05 & 12.47 & $0.00^{* *}$ \\
Autonomy & 0.29 & 0.17 & 0.08 & 3.90 & $0.00^{* *}$ \\
Interaction & 0.20 & 0.13 & 0.07 & 2.89 & $0.00^{*}$ \\
Task requirement & 0.18 & 0.11 & 0.07 & 2.36 & $0.02^{*}$ \\
Years of working & 0.01 & 0.09 & 0.01 & 2.24 & $0.03^{*}$ \\
experience as a & & & & & \\
nurse & & & & & \\
\hline
\end{tabular}

$\mathrm{R}=0.56, \mathrm{R}^{2}=0.33$, Adjusted $\mathrm{R}^{2}=0.32, \mathrm{~F}=40.43,{ }^{*} \mathrm{p}<.05$, ** $\mathrm{p}$ $<.01$

Table IV. Multiple regression analysis of the factors predicting organizational commitment $(n=416)$

\section{DISCUSSION}

The first objective of this study was to determine the level of organizational commitment among nurses in state hospitals. The results indicated that nearly half of the subjects reported high organizational commitment. This means that their degree of loyalty to their hospitals is quite strong, which gives sufficient belief to say that if they find a good offer elsewhere they will not leave their hospitals. There are many possible explanations that can be employed to explain this finding.

Firstly, the four state hospitals have been accredited by Malaysian Society for Quality in Health (MSQH) which is the national accrediting body for healthcare facilities and services in Malaysia. ${ }^{32}$ This showed that the state hospitals have met the accreditation standard and are well recognized, therefore, nurses who work in this hospital should be proud to be part of the organizations which may lead to the high level of organizational commitment.The data revealed that nearly half of the subjects $(45.67 \%)$ reported that they were glad that they were chosen by their current hospitals to work $(\bar{X}=5.12, \quad S D=1.51$; Appendix A), $44.47 \%$ of the subjects stated that their current hospital is the best of all possible organizations for them $(\bar{X}=5.10, S D=1.40$; Appendix $A)$, and they were proud to tell others that they are part of the organization $(\bar{X}=5.06, S D=1.43$; Appendix $A)$. Secondly, the benefits, including pension benefits, annual leave, maternity leave, housing loan, car loan and medical benefits were provided by the organization to the nurses. In the situation of economic crisis as well as the increasing of medical

\begin{tabular}{|c|c|c|c|c|c|}
\hline Statements & $\bar{x}$ & SD & $\begin{array}{l}\text { Low } \\
(\%)\end{array}$ & $\begin{array}{l}\text { Moderate } \\
(\%)\end{array}$ & $\begin{array}{l}\text { High } \\
(\%)\end{array}$ \\
\hline $\begin{array}{l}\text { I willing to put in a great deal of } \\
\text { effort beyond that normally } \\
\text { expected in order to help this } \\
\text { organization be successful }\end{array}$ & 5.08 & 1.37 & 13.95 & 46.63 & 39.42 \\
\hline $\begin{array}{l}\text { I talk up this organization to my } \\
\text { friends as a great organization to } \\
\text { work for. }\end{array}$ & 4.86 & 1.51 & 24.28 & 38.22 & 37.50 \\
\hline $\begin{array}{l}\text { I would accept almost any type of } \\
\text { job assignment in order to keep } \\
\text { working for this organization. }\end{array}$ & 4.78 & 1.45 & 22.36 & 45.19 & 32.45 \\
\hline $\begin{array}{l}\text { I find that my values and the organi- } \\
\text { zation's values are very similar. }\end{array}$ & 4.55 & 1.42 & 27.64 & 45.67 & 26.69 \\
\hline $\begin{array}{l}\text { I am proud to tell others that I am } \\
\text { part of this organization. }\end{array}$ & 5.06 & 1.43 & 16.35 & 41.83 & 41.82 \\
\hline $\begin{array}{l}\text { This organization really inspires the } \\
\text { very best in me in the way of job } \\
\text { performance. }\end{array}$ & 4.95 & 1.50 & 19.72 & 39.90 & 40.38 \\
\hline $\begin{array}{l}\text { I am extremely glad that I chose } \\
\text { this organization to work for over } \\
\text { others I was considering at the time } \\
\text { I joined. }\end{array}$ & 5.12 & 1.51 & 18.99 & 35.34 & 45.67 \\
\hline $\begin{array}{l}\text { I really care about the fate of this } \\
\text { organization. }\end{array}$ & 5.09 & 1.40 & 14.90 & 43.75 & 41.35 \\
\hline $\begin{array}{l}\text { For me this is the best of all possible } \\
\text { organizations for which to work. }\end{array}$ & 5.10 & 1.40 & 16.82 & 38.71 & 44.47 \\
\hline
\end{tabular}

expenses, nurses are able to maintain their quality of life with the benefits provided by the government. Appendix A: Mean, standard deviation and percentage of each items of OCQ $(n=416)$

Thirdly, due to the placement of a physician in acute care unit in state hospitals. Most of acute care units in the state hospital have physicians who work around the clock in the unit. This creates a less stressful situation to nurses because there are physicians available all the time for consultation in any emergency situation. Fourth reason is the working culture in the hospitals. As Malaysia still strongly preserves with Asian cultures, which uphold the core values of shared values and community orientation, as opposed to the Western values that promote active competitiveness and individualism. ${ }^{33}$

Likewise, in state hospitals, the value is upheld by most healthcare providers. The nurses have a tendency to help each other whenever necessary whereby others' needs or team needs are put before individual needs compared to the Western, which is more individualism. This value can create strong bonds and encourage teamwork spirit as well as increasing the friendliness, healthy relationship and sense of belonging to the organizations. Healthy relationship is based on trust, mutual respect and open communication. ${ }^{34}$ Research suggests that good relationship within and between the groups of nurses will encourage team work and which in turn increases staff commitment and reduced turnover. ${ }^{15}$ Therefore, nurses who experience a good relationship with others will report high organizational commitment. Lastly, it is due to the marital status of the subjects. Our data revealed that the majority of the subjects were married $(60.58 \%)$. Married nurses have greater 
financial burdens and family responsibilities than unmarried nurses. Leaving their current organization may interfere with their family life. Therefore, married nurses tend to report a high level of organizational commitment as some studies found that marital status has a positive relationship with organizational commitment. ${ }^{15,35}$

Second objective of the study was to identify a set of variables that predict organizational commitment among nurses in state hospitals. Based on the literature, the examined predictors of organizational commitment included perceived organizational support, components of job satisfaction (pay, autonomy, interaction, organizational policies, task requirement and professional status) and years of experience. The finding indicates that professional status, autonomy, interaction, task requirement and years of experience could predict the organizational commitment. Overall, it implies that these five predictors explain 33\% of the total variance in the organizational commitment. The other $67 \%$ of variability of organizational commitment can be explained by other factors which were not explored in this study. These results are consistent with previous studies that show that some of the components of job satisfaction and years of experience were influential in explaining organizational commitment among nurses. ${ }^{9,11,14,22,23,36,37}$ Professional status was the strongest predictor of organizational commitment $(\beta=0.52, p<0.01)$. This showed that nurses who were satisfied with their professional status were committed to their organizations. This finding was consistent with a study of Jernigan and colleague. ${ }^{37}$ The finding suggested that if nurses and nursing care in the hospitals were appreciated by others, especially patients, relatives, physicians and other healthcare providers, nurses may feel that they are treated as important persons in the hospitals. Therefore, they are more likely to be satisfied with the professional status and will not leave their organizations as found in a study, reported nurses who were highly satisfied with their professional status tend to be highly committed to their organizations. ${ }^{11,37}$

Autonomy was the second predictor of organizational commitment $(B=0.17, p<0.01)$. Nurses who were satisfied with their autonomy were highly committed to their organizations. This result was congruent with two others studies that found that job autonomy was significant predictor of affective commitment. ${ }^{36,37}$ Nurses who had adequate responsibility, being trusted to carry out their tasks, can take control over their work activities and had authority to make decisions to provide nursing care will be satisfied with their autonomy. These will create a sense of achievement and more importantly, a sense of belonging which will increase the level of commitment towards their current hospitals as studies reported that nurses who were satisfied with their autonomy were highly committed to their organizations. ${ }^{11,36}$

Interaction was the third predictor of organizational Volume 10 Number 2, Dec 2011 commitment $(\beta=0.13, p<0.05)$. Nurses who were satisfied with the nurse and nurse's interaction and nurse and physician's interaction were committed to their organizations. This finding was consistent with few studies that showed that interaction was positively correlated with organizational commitment. ${ }^{11,21}$ Contrary to the finding of a study that indicated that interaction could not predict the organizational commitment. ${ }^{37}$ Contradiction of the results could be due to the majority of the subjects in this study was from the same age group of 21 to 40 years old (86.53\%). This may encourage a positive interaction and a good team work among them, which can create strong bonds and encourage teamwork spirit as well as increasing the affection and sense of belonging to the institution.

Task requirements emerged as the forth predictor of organizational commitment $(\beta=0.11, p<0.05)$. A task requirement refers to the task that must be done as a regular part of the job and organization of work as it relates to the amount of time allotted to patient care and administrative work. This means nurses who have sufficient time to do their regular work and administrative work in the time frame will be committed to their organizations. This result was in accordance to other studies that show that nurses who were satisfied with their task requirement or work it-selfs were found to be committed to their organizations. ${ }^{11,22,23,38}$ However, the finding contradicted to a study who found that task requirement had no relationship to organizational commitment and was not a significant predictor of organizational commitment. ${ }^{37}$ This might be due to good delegation of work by nurse managers and lessening the use of paper in most of the documentation in the state hospitals of Malaysia. This will lessen the clerical and paper work of nurses and gives sufficient time for them to provide direct patient care, and discuss patient-care problems with other nursing personnel. Thus, these nurses will perform better in their job, In turn they would be satisfied with their activities that they do on their job and will be committed to their organizations.

Lastly, years of experience emerged as the last predictor of organizational commitment $\beta=0.09$, $\mathrm{p}<0.05)$. Nurses who had long years of experience were reportedly highly committed to their organizations. The predictability of years of experience on organizational commitment in this study was small, but this result is congruent with the concept of Mowday, Porter and Steer that proposed that commitment was developed within an individual by the process of self-reinforcing cycles of attitudes and behaviors that progress on the job and over time strengthen employee's commitment to the organization. ${ }^{39}$ This showed that the longer nurses work with the organization, the more of sense of belonging which influence the attitudes and behavior to remain in the organization. Despite considerable literature suggesting links between years of experience and organizational commitment, few studies found nurses with longer years of experience were highly committed 
to their organizations.9,13,14,24 The positive relationship between years of experience and organizational commitment might be due to the fact that the longer period of working will accumulate to much benefit such as high salary, high increment, more annual leave, good pension plan, bonus and other benefits. In addition, nurses with longer years of experience mostly occupy higher positions, more responsibility, which provides more opportunities for involvement in decision-making and are better integrated into the workplace. Those nurses have a better career ladder which creates a sense of achievement among them. Therefore, they tend to be committed to their organization than those with shorter years of experience. The remaining three variables including POS, organizational policies and pay did not contribute to the prediction of the organizational commitment among nurses in state hospitals of Malaysia. Interestingly, POS and Organizational policy were found positively related to organizational commitment but could not predict the organizational commitment. This may be because POS and organizational policies have a strong correlation with other predictors and of it shared variance with other predictor variables. Furthermore, pay was found to have a low correlation with organizational commitment, and therefore, pay could not predict the organizational commitment. This result was in accordance with two previous studies. ${ }^{22,37}$ This tends to suggest that high pay does not translate to strong organizational commitment. This result is congruent with the concept of Porter,who proposed that commitment can be influenced by affective rather than economic factors. ${ }^{6}$

\section{CONCLUSION}

As the findings of the study show that Malaysian nurses were quite highly committed to their organizations while there was high turnover of nurses in Malaysia, organizational commitment may not be a good indicator for turnover of Malaysian nurses. Furthermore, it needs to be noted that the four selected state hospitals had a low turnover rate, between 1.4 to $2.3 \%$ in the year 2010, which may give information that nurses who are working in the studied hospitals obviously tend to be committed to their organization.

Given to the present situation, it is strongly recommended that nursing administrators should consider and maintain those predictors in nursing practice to foster a high level of organizational commitment. Furthermore, hospital and nursing administrators should pay more attention in retaining nurses with long years of experience by providing a good career ladder because these nurses are able to perform well and able to provide quality nursing care and efficiency and effectiveness of the organization will be increased.

\section{Recommendation for future research}

To have a better understanding of organizational commitment and turnover, future studies should take other variables such as leadership style and empowerment into account to find the predictive ability of those variables to organizational commitment and turnover.

\section{Acknowledgements}

We wish to extend our heartfelt gratitude to the Hospital Director of the four selected hospitals for their kindness to give permission prior to this study.

Additional thanks are owed to the nurses in the hospitals for their participation and consent.

\section{REFERENCES}

1. Laschinger HKS, Purdy N, Cho J, Almost J. Antecedents and Consequences of Nurse Managers' Perceptions of Organizational Support. Nursing Economics 2006; 24: 20-29.

2. Rhoades L, Eisenberger R. Perceived Organizational Support: A Review of the Literature. J Appl Psychol 2002; 87: 698-714.

3. Zangaro GA. Organizational Commitment: A Concept Analysis. Nursing Forum 2001; 36: 14-22.

4. Mowday RT, Steers RM, Porter LW. The Measurement of Organizational Commitment. J Vocational Behavior 1979; 14: 224-247.

5. Meyer JP, Allen NJ. Commitment in the Work place: Theory, Research, and Application. California: Sage Publications, 1997.

6. Porter LW, Steers RM, Mowday RT, Boulian PV. Organizational Commitment, Job Satisfaction and Turnover among Psychiatric Technicians. J Appl Psychol 1974; 59: 603609.

7. Rodwell J, Noblet A, Demir D, Stene P. The Impact of the Work Condition of Allied Health Professionals on Satisfaction, Commitment, and Psychological Distress. Health Care Manage Rev 1990; 34: 273-283.

8. Al-Hussaini M. A Study of Nurses' Job Satisfaction: The Relationship to Organizational Commitment, Perceived Organizational Support, Transactional Leadership, Transformational Leadership and Level of Education. Eur J Scientific Res 2008; 22: 286-295.

9. Al-Aameri A S. Job Satisfaction and Organizational Commitment for Nurses. Saudi Med J 2000; 21: 531-535.

10. Gregory DM, Way CY, LeFort S, Barrett BJ, Parfrey PS. Predictors of Registered Nurses' Organizational Commitment and Intent to Stay. Health Care Manage Rev 2007; 32: 119-127.

11. Ingersoll GL, Olsan T, Drew-Cates J, DeVinney BC, Davies J. Nurses' Job 
Satisfaction, Organizational Commitment, and Career

Intent. J Nurs Adm 2002; 32: 250-263.

12. Lok P, Crawford J. Antecedents of Organizational Commitment and the Mediating Role of Job Satisfaction. Journal of Managerial Psychology 2001; 16: 594-613.

13. Cohen A. Age and Tenure in Relation to Organizational Commitment: AMeta-Analysis. Basic Appl Soc Psych 1993: 14: 143-159.

14. Jahangir F, Shokrpour N. Three Components of Organizational Commitment and Job Satisfaction of Hospital Nurses in Iran. Health Care Manag (Frederick) 2009; 28: 375-380.

15. Sikorska-Simmons E. Predictors of Organizational Commitment among Staff in Assisted Living. Gerontologist 2005; 45: 196205.

16. George JM, Reed TF, Ballard KA, Colin J, Fielding J. Contact with AIDS Patients as a Source of Work-Related Distress: Effects of Organizational and Social Support. Acad Manage J 1993; 36: 157-171.

17. Stamps PL. Nurses and work satisfaction: An index for measurement. 2nd ed. Chicago, IL: Health Administration Press, 1997.

18. Shore LM, Martin HJ. Job Satisfaction and Organizational Commitment in Relation to Work Performance and Turnover Intention. Human Relations 1989; 42: 625-638.

19. Wu L, Norman IJ. An Investigation of Job Satisfaction, Organizational Commitment and Role Conflict and Ambiguity in a Sample of Chinese Undergraduate Nursing Students. Nurse Educ Today 2006; 26: 304-314.

20. Fang Y. Turnover propensity and its causes among Singapore nurses: An empirical study. International Journal of Human Resource Management 2001; 12: 859-871.

21. Ishida M. Professional Commitment, Organizational Commitment and Job Satisfaction of Nurses. Bull Coll Med Sci Tohoku Univ 2000; 9: 145-152.

22. Knoop R. Relationship among Job Involvement, Job Satisfaction and Organizational Commitment for Nurses. J Psychol 1995; 129: 643-647.

23. Tsai MT, Huang CC. The Relationship among Ethical Climate Types, Facets of Job Satisfaction, and the Three Components of Organizational Commitment: A Study of NursesinTaiwan. JBusEthics 2007; 80:565-581.

24. Kuokkanen L, Leino-Kilpi H, Katajisto J. Nurse Empowerment, Job-related Satisfaction and Organizational Commitment. J Nurs Care Qual 2003; 18: 184-192.

25. Ahmad A. Rencana Utama: Jururawat Malaysia di Tanah Arab [online]. Available at: http://www.Kosmo_Online-RencanaUtama. mht. Accessed May 20, 2011.

26. Barnett T, Namasivayam P, Narudin DAA. A Critical Review of the Nursing Shortage in Malaysia. International Nursing Review 2010;
57: 32-39.

27. Ahmad N, Oranye O. (2010). Empowerment, Job Satisfaction and Organizational Commitment: AComparative Analysis of Nurses Working in Malaysia and England. J Nurs Manag 2010; 18: 582-591.

28. Masroor MA, Fakir MJ. Level of Job Satisfaction and Intent to Leave among Malaysian Nurses. Business Intelligence Journal 2009; 3: 123-137.

29. Param JS, Raja Jamaluddin RAM. Job Satisfaction among Staff Nurses in Kuala Lumpur Hospital in 1996. The Asian Journal of Humanities 1996; 12: 60 - 72.

30. Pearson L, Chong J. Contributions of job content and social information on commitment and job satisfaction: An exploration in a Malaysian nursing context. J Occup Organ Psychol 1997; 70: 357-374.

31. Eisenberger R, Huntington R, Hutchinson $S$, Sowa D. Perceived Organizational Support. J Appl Psychol 1986; 71: 500-507.

32. Abraham M. Hospital Accreditation in Malaysia. Available at: http: / /www.quality.kck.usm. my. Accessed June 2, 2011

33. Khoo BT. The Value(s) of a Miracle: Malaysian and Singaporean Elite Constructions of Asia. Asian Studies Review 1999; 23: 181-192.

34. Manion J. Strengthening Organizational Commitment: Understanding the Concept as a Basis for Creating Effective Workforce Retention Strategies. Health Care Manag (Frederick) 2004; 23: 167-176.

35. Makanjee CR, Hartzer YF, Uys IL. The Effect of Perceived Organizational Support on Organizational Commitment of Diagnostic Imaging Radiographers. Radiography 2006; 12: 118-126.

36. Galletta M, Portoghese I, Battistelli A. Intrinsic Motivation, Job Autonomy and Turnover Intention in the Italian Healthcare: The Mediating Role of Affective Commitment. Journal of Management Research 2011; 3: 1-19.

37. Jernigan E, Beggs JM, Kohut GF. Dimensions of Work Satisfaction as Predictors of Commitment Type. Journal of Managerial Psychology 2002; 17: 564-579.

38. Bateman T, Strasser S. A Longitudinal Analysis of the Antecedents of Organizational Commitment. Acad Manage J 1984; 21: 95 - 